\title{
"Creating innovative design labs for the public sector: A case for institutional capacity building in the regions of Ukraine"
}

\begin{tabular}{|c|c|}
\hline \multirow{5}{*}{ AUTHORS } & Dmytro Dzvinchuk (iD) \\
\hline & Mariana Orliv (iD) \\
\hline & Brigita Janiunaite \\
\hline & Victor Petrenko (D) \\
\hline & $\mathbf{R}$ \\
\hline ARTICLE INFO & $\begin{array}{l}\text { Dmytro Dzvinchuk, Mariana Orliv, Brigita Janiunaite and Victor Petrenko (2021). } \\
\text { Creating innovative design labs for the public sector: A case for institutional } \\
\text { capacity building in the regions of Ukraine. Problems and Perspectives in } \\
\text { Management, 19(2), 320-332. doi:10.21511/ppm.19(2).2021.26 }\end{array}$ \\
\hline DOI & http://dx.doi.org/10.21511/ppm.19(2).2021.26 \\
\hline RELEASED ON & Monday, 21 June 2021 \\
\hline RECEIVED ON & Friday, 16 April 2021 \\
\hline \multirow[t]{2}{*}{ ACCEPTED ON } & Thursday, 10 June 2021 \\
\hline & $((c))_{E Y}$ \\
\hline LICENSE & $\begin{array}{l}\text { This work is licensed under a Creative Commons Attribution } 4.0 \text { International } \\
\text { License }\end{array}$ \\
\hline JOURNAL & "Problems and Perspectives in Management" \\
\hline ISSN PRINT & $1727-7051$ \\
\hline ISSN ONLINE & $1810-5467$ \\
\hline PUBLISHER & LLC "Consulting Publishing Company "Business Perspectives" \\
\hline FOUNDER & LLC "Consulting Publishing Company "Business Perspectives" \\
\hline
\end{tabular}

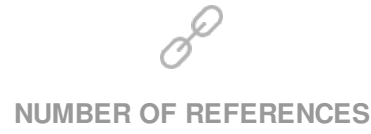

43

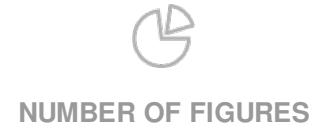

1
NUMBER OF TABLES

2

(C) The author(s) 2021. This publication is an open access article. 


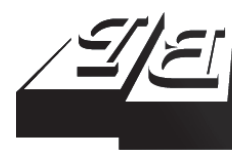

\section{BUSINESS PERSPECTIVES}

LLC "CPC "Business Perspectives" Hryhorii Skovoroda lane, 10, Sumy, 40022, Ukraine www.businessperspectives.org

Received on: $16^{\text {th }}$ of April, 2021 Accepted on: $10^{\text {th }}$ of June, 2021 Published on: $21^{\text {st }}$ of June, 2021

(C) Dmytro Dzvinchuk, Mariana Orliv, Brigita Janiunaite, Victor Petrenko, 2021

Dmytro Dzvinchuk, Doctor of Science in Philosophy, Professor, Director of the Institute of Humanities and Public Administration, Ivano-Frankivsk National Technical University of Oil and Gas, Ivano-Frankivsk, Ukraine.

Mariana Orliv, Doctor of Science in Public Administration, Associate Professor, Head of the Department of Public Administration and Management, Ivano-Frankivsk National Technical University of Oil and Gas, Ivano-Frankivsk, Ukraine. (Corresponding author)

Brigita Janiunaite, Doctor in Social Sciences, Principal Investigator of the Educational Research Group, Professor, Faculty of Social Sciences, Arts and Humanities, Kaunas University of Technology, Kaunas, Lithuania.

Victor Petrenko, Doctor of Science in Economics, Professor, Professor at the Department of Public Administration and Management, Ivano-Frankivsk National Technical University of Oil and Gas, Ivano-Frankivsk, Ukraine.

This is an Open Access article, distributed under the terms of the Creative Commons Attribution 4.0 International license, which permits unrestricted re-use, distribution, and reproduction in any medium, provided the original work is properly cited.

Conflict of interest statement: Author(s) reported no conflict of interest
Dmytro Dzvinchuk (Ukraine), Mariana Orliv (Ukraine), Brigita Janiunaite (Lithuania), Victor Petrenko (Ukraine)

\section{CREATING INNOVATIVE} DESIGN LABS FOR THE PUBLIC SECTOR: A CASE FOR INSTITUTIONAL CAPACITY BUILDING IN THE REGIONS OF UKRAINE

\begin{abstract}
Innovative design labs were created by public authorities of the USA, Australia, Singapore, Finland, Canada, the UK, Switzerland, Denmark, China, and other countries to accelerate changes and develop modern public service. This paper provides further insight to establishing external innovation accelerators for strengthening capacity of public institutions. The study aims to define the development opportunities for innovative design labs for the public sector in Ukraine's regions by the case of the Laboratory of Intellectual Development for Empowering Regions (LIDER). The study was conducted at two stages: (1) exploring the features of innovation implementation in the public sector and outlining the main problems of innovation capacity of public institutions; (2) defining the development opportunities for the LIDER via SWOTanalysis. To substantiate the study results, the correlation analysis between autocratic, bureaucratic, competitive, self-protective, and participative leadership behaviors of CEOs and innovation index based on data from 18 countries was performed, as well as a survey of 195 public servants of the Ministry of Justice of Ukraine and an interview of 9 experts were conducted.

The following key development opportunities for the LIDER were detected: promoting the introduction of incremental innovations in public institutions by using design thinking methodology; assisting the development of pro-innovative culture and participative leadership via individual-centric and system-oriented approaches; developing effective tools for performance management and supporting public institutions in project activity; organizing the competitions for regional innovative projects; assisting in creation of radically human systems in public institutions.
\end{abstract}

Keywords

innovation, public institutions, design thinking, bureaucracy, leadership, training

JEL Classification O31, R58

\section{INTRODUCTION}

In 2018, the World Bank defined institutional capacity building as one of five key factors for enhancing the public sector performance. Therefore, its newly established Bureaucracy Lab aims at fostering research and innovation to make the government workforce more productive through training and capacity-building programs (World Bank Group, 2018). Similar innovative design labs were established in the USA, the United Kingdom, Australia, Singapore, Finland, Canada, Switzerland, Denmark, China, and other countries (Apolitical, 2019) to foster innovation, spin-off initiatives in different public institutions and levels of government, and train public servants in the application of design thinking approaches (Allio, 2014). For instance, the Lab at 
the Office of Personnel Management in the USA was created "for building human-centered design capabilities across public sector workforce, through project-based learning, a comprehensive design curriculum, and through leadership on design in government" (Rao et al., 2019, p. 60). The Human Experience Lab in Singapore facilitates inter-agency and government-citizen collaboration and co-creation to build an innovative and responsive public service (Lau et al., 2016). The Open Innovation Team at the Cabinet Office of the United Kingdom was created "to strengthen ties with academics and tab into their expertise to foster innovation" (Rao et al., 2019, p. 58). According to OECD observatory of public sector innovation, although innovation is considered important by governments, it may take a long time to spread it among senior executives in different institutions (OECD, 2018).

The experience of these innovative design labs is extremely useful for Ukraine, because of the need for decentralization of power, which was defined as one of the priority reforms and highlights the problem of creating such innovation accelerators for the public sector not only in the central government but also in the regions to meet the needs of regional administration and local self-government. However, in the implementation of their experience, it is necessary to determine the development opportunities for such innovative design labs based on not only on results of qualitative single-country case studies, but also on empirical and comparative research, focused on the investigation of the main problems and features of the innovation capacity of public institutions.

\section{LITERATURE REVIEW}

American and Anglo-Saxon perspective is central when studying innovation in the public sector (De Vries et al., 2015), but some of the results cannot be applied to other cultures and countries (Demircioglu \& Audretsch, 2017). Therefore, empirical studies to assess the innovation capacity of public institutions and to substantiate effective innovation management tools, which can be used in design labs, for recent years have been carried out by university scientists from other countries individually and by teams of experts from international organizations, which realize research programs and competitions for innovation projects. In particular, Meijer $(2019$, p. 626) from Utrecht University in the Netherlands has developed the instrument for testing the public innovation capacity and defined that "the Municipality of Utrecht has started experiments and coordinated different innovation efforts, but its capacity to mobilize innovative forces, to capitalize on the experiments and to weigh different values and interests could be developed further". Gellen (2017, p. 51) from the National University of Public Service in Hungary based on the results of empirical analysis on the innovative capacity of the Hungarian public service concluded that "innovators can be found in a hierarchic traditional public administration system, but their ambition is a classical bureaucratic one: to increase their own bureaucratic influence". Teodoro (2009, p. 178) from the USA holds a similar view: "Sitting atop an agency with vertical advancement, the bureaucrat is not so interested in pursuing professional innovations".

However, this does not apply to all countries and systems. For instance, bureaucratic organizational structure in Lithuanian public institutions is one of the main barriers impeding public sector innovation, but senior executives are the key initiators of change because of "a strong commitment to innovation and the political will to implement it in the public sector" (Zidonis et al., 2020, p. 394). Other experts acknowledge that it can be difficult to measure the impact of leadership on organizational change (Harb \& Sidani, 2019).

Besides, Demircioglu and Audretsch (2018) proved that the innovativeness of public institutions does not always depend on senior government officials. Bureaucratic public organizations dissatisfied employees value invention and innovative ideas, therefore their efforts "may be more important than leadership support and an existing positive climate", which "do not have a statistically significant impact on innovation complexity" (Demircioglu \& Audretsch, 2018, p. 834). In contrast to this position, Berry and Berry (1990, p. 399) identified "two factors that increase the probability of innovation in an organization: the 
motivation to innovate and the availability of resources for overcoming obstacles".

Unfortunately, the results of studies conducted by the National Academy for Public Administration under the President of Ukraine and the Institute of Economy and Forecasting of the National Academy of Sciences of Ukraine showed that the high level of functional incompetence of public servants that reached the value of $80 \%$ resulted in a low level of their readiness (up to $4.7 \%$ ) to perform functions at the required level of productive activity (Afonin \& Balakireva, 2015). While Dutch scholars interpret public innovation capacity as a capacity to develop and implement new ideas for societal problems (Meijer, 2019), the representatives of the Ukrainian School of Archetypes identify the following problems of public administration reform implementation: inefficient bureaucratic system of public service, its isolation from the community, lack of demand for initiatives and innovative ideas, and lack of qualified workforce due to low wages (Afonin \& Balakireva, 2015). In 2018 this led to the last place of Ukraine in the ranking of 36 countries according to the level of innovation index (European Commission, 2019).

Thus, it should be recognized that, firstly, different countries have their problems of strengthening the innovation capacity of public institutions, and secondly, there is no consensus among researchers and experts on success factors and barriers to innovation in the public sector. Lapuente and Suzuki (2020, p. 454) emphasize that "past research has generally relied on qualitative single-country case studies or comparative studies of a few countries". Thus, large comparative research, focused on the investigation of the innovative public institutions development, are unusual. And, therefore, the hypothesis of the influence of bureaucracy and leadership on the innovativeness of public institutions can be neither confirmed nor refuted.

Besides, to develop measures for institutional capacity building in the public sector through innovations it is necessary to find out the peculiarities of their recognition, measurement, and dissemination. According to European experts, for this purpose, the fourth edition of the Oslo Manual 2018, jointly published by the OECD and Eurostat (2018), can be used, as it is a point of departure for recognition and measurement of innovations in the public sector. However, there are some areas where in-depth research is required (Arundel et al., 2019; Sandor, 2018).

A literature review allows concluding that the establishment of innovative design labs for the public sector in the regions of Ukraine must be preceded by quantitative and qualitative analysis of the above aspects. Thereby, the purpose of the study is to define the development opportunities for innovative design labs for the public sector in the regions of Ukraine by the case of the Laboratory of Intellectual Development for Empowering Regions (LIDER) based on the results of analysis of the main features and problems of the innovation capacity of public institutions.

\section{METHODOLOGY}

To identify the main features and problems of recognition, measurement, and dissemination of innovations in the public sector on stage 1, quantitative analysis was supplemented by dialectical research and content analysis using the results of studies conducted by OECD and Eurostat (2018), OECD (2019), consulting company Accenture (Alon et al., 2016), National Agency of Ukraine for Civil Service (2019) and other empirical academic research on public sector innovation.

The correlation analysis was conducted to investigate how innovativeness is influenced by the leadership behaviors of CEOs (autocratic, bureaucratic, competitive, self-protective, and participative). The empirical basis for correlation analysis is the data from the European innovation scoreboard 2019 (European Commission, 2019) and the results of the research program "Global Leadership and Organizational Behavior Effectiveness" (GLOBE, 2020). The sample of observations is 18 countries which were included in both empirical research (Austria, the Czech Republic, Finland, France, Germany, Greece, Hungary, Ireland, Israel, Italy, the Netherlands, Poland, Portugal, Slovenia, Spain, Sweden, Switzerland, and the United Kingdom). For this sample, Pearson's correlation coefficient was calculated to measure the statistical relationship between the variables, and the Shapiro-Wilk test was performed to exam if they are normally distributed in a population. Based on the results of correlation analysis, the leadership behaviors that contribute to 
the formation of the innovation capacity of institutions have been clarified.

To identify the main barriers to innovation in public institutions, in 2020 a survey of 195 public servants of the Ministry of Justice of Ukraine was conducted. The choice of this institution is due to the fact that the results of empirical research by Lapuente and Suzuki (2020, p. 463) obtained after two large unique comparative data sets on public bureaucracies and public managers in European countries proved that "bureaucratic organizations creating a more innovative culture will be those where most public managers do not have legal training".

On stage 2, based on the results of experts' interviews $(n=9)$ that were familiar with the conclusions of the first stage of this research, the development opportunities for the LIDER as an innovation accelerator for the public sector were defined via the SWOT-analysis.

\section{RESULTS AND DISCUSSION}

\subsection{The problems and features of the innovation capacity of public institutions}

The results of correlation analysis between CEOs' leadership behavior and innovation index in dif- ferent counties (Figure 1), which was conducted on the basis of the GLOBE research program (GLOBE 2020) and the European Commission (2019) data, indicates the inverse correlation between bureaucratic leadership and innovation index, as well as between self-protective leadership and innovation index that is expected to be strong $(-0.793$ and -0.769 respectively with the level of significance $<0.01)$. A slightly less significant inverse relationship is found between the internally competitive leadership and innovation index $(-0.661$ with the level of significance $<0.05)$. These three types of leadership also correlate with each other.

Positive but not strong enough correlation between participative leadership and innovation index $(0.597$ with the level of significance $<0.1)$ means that it is important not only to involve others in decision-making but also to create an innovative culture and attract motivated professionals who have the necessary competences for innovative changes introduction. This is confirmed by the results of a survey of 195 public servants of the Ministry of Justice of Ukraine. Respondents pointed the following barriers to innovation in public institutions: bureaucracy (42.9\%); unwillingness of public servants to change (41.9\%) and low level of their motivation (35.2\%); lack of time (34.3\%), funding (21.9\%), necessary knowledge and skills (20\%) and leaders (19.1\%). These figures
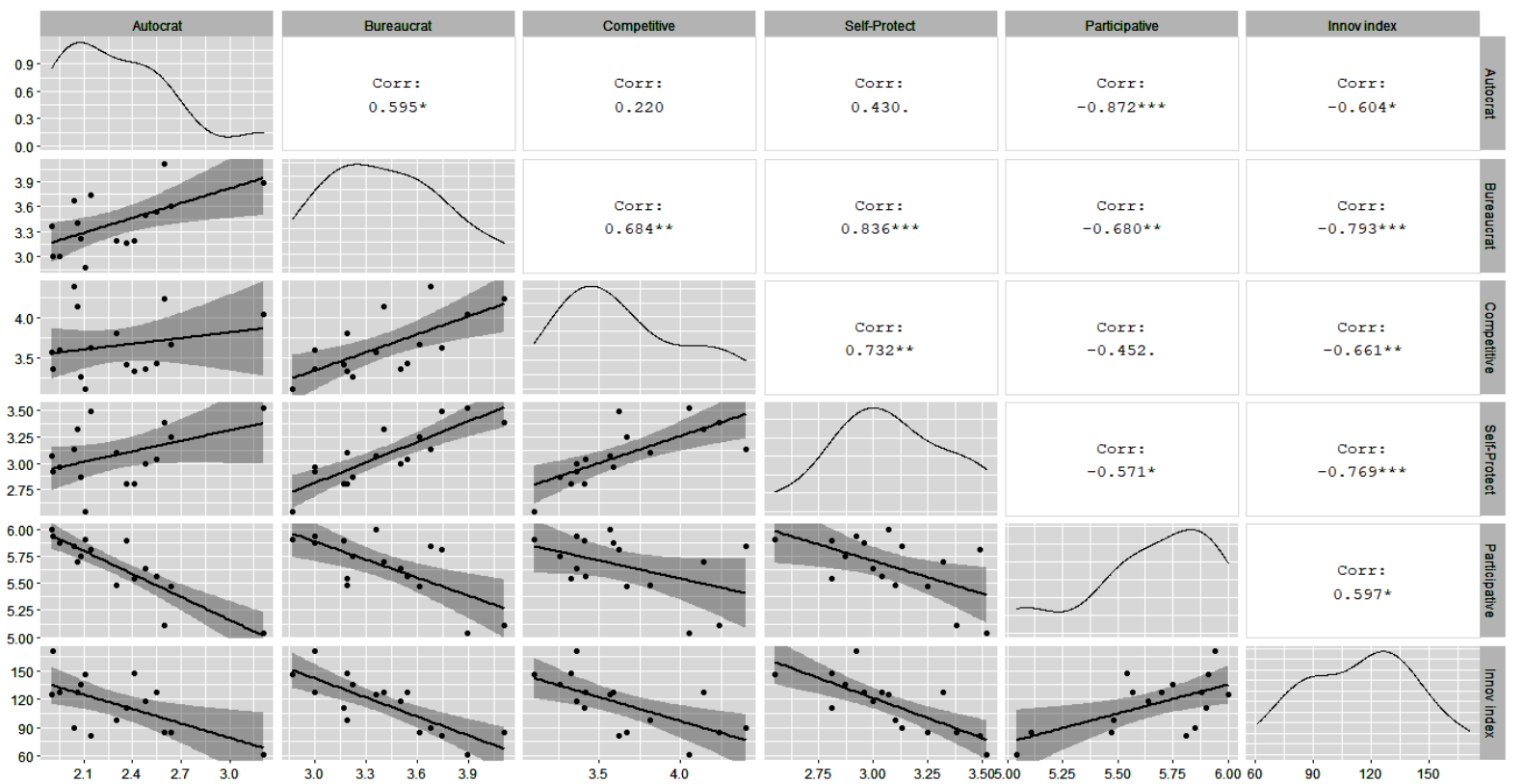

Figure 1. Visualization of correlation analysis between leadership behaviors and innovation index 
also support Demircioglu and Audretsch (2018), and Sahni et al. (2013) who testified that a public institution with supportive and high-quality leadership culture will still fail to innovate without motivated employees with the required level of competence.

In identifying the main features and problems of recognition, measurement, and dissemination of innovations in the public sector using the Oslo Manual (OECD \& Eurostat, 2018) the following aspects are considered:

(1) Lack of normative component in interpretation of the meaning of the term "innovation" in the Oslo Manual, because of recognition a new or improved product or process as an innovation it "differs significantly from the firm's previous products or business processes" (OECD \& Eurostat, 2018, p. 20). There is no comparison with other public institutions, foreign practice, private sector as well as no requirement for market novelty. Scientific publications on public sector innovation in peer-reviewed journals also do not offer a solution to this problem. According to Bloch (2011, p. 20), "innovations must be new to your organization, although they can have been developed by others". Therefore, innovation in the public sector can take different forms. For instance, Torugsa and Arundel (2016) defined its following forms: policy, service, administrative and organizational, service delivery, and conceptual innovation. De Vries et al. (2015) differentiated between process innovation, product or service innovation, governance, conceptual and other innovation. Herewith, conceptual innovation can be identified as the "development of new world views that challenge assumptions that underpin existing service products, processes and organizational forms" (Windrum, 2008, p. 9). Witell et al. (2016) reviewed definitions of service innovation in 1301 articles and identified 84 different ones. In scientific literature on public administration such concepts are present: "architectural innovation", "enhancement-oriented innovation", "adaptive innovation", "anticipatory innovation", "substitutes", etc. Such an approach not only encompasses a broad range of innovation, from minor incremental improvements
(Bugge \& Bloch, 2016) to disruptive or radical innovation that completely changes or replaces processes and services (Osborne \& Brown, 2011) but also complicates the demarcation of innovation from other similar phenomena. It should be noted that in practice, firstly, different types of innovations often create hybrid or complex ones (for instance, an innovation that improves the organizational process and increases not only efficiency but also customer satisfaction), and secondly, series of incremental innovations in the public sector, which involve discontinuous changes, can bring even greater benefits than a radical one. Therefore, the differentiation of innovations "needs to be understood and reflected within public policy and its implementation" (Osborne \& Brown, 2011, p. 1342), administrative process improvement, new public services creation, etc., rather than be reduced to sophistry.

(2) For the public sector, information about the innovation process itself is crucial. Therefore, the results of a systematic literature review of 181 articles and books on public sector innovation, conducted by De Vries et al. (2015) indicated that innovations, which are focused on improving the quality and increasing the effectiveness and efficiency of internal and external processes, are most common for public institutions. The same opinion is held by Arundel et al. (2019, p. 790): "In comparison with the private sector, policy interest in public sector innovation is more concerned with innovation process, or how innovation occurs, in order to increase the use of innovation to solve problems and improve innovation outcomes". Due to various political, economic, social, mental, cultural, and other features, as well as the external and internal environment, this process is almost impossible to repeat, but it can be adapted. Innovations in the public sector are often driven by ideas of the New Public Management and e-governance. Therefore, central or local governments are more likely to benefit from hiring agency heads from outside, as this provides a better chance of implementing innovations than when agency heads are promoted from within (Teodoro, 2009). Such practice is aimed at solving the problem raised in the "2015 US 
Innovation Survey" conducted by consulting company Accenture. The results of this study testified that not only a lack of enthusiasm, confidence, or investment are the main barriers for innovation performance, but also the fact that the vast majority of executives of organizations do not distinguish how they innovate from how they go about achieving incremental performance gains. This seemed to lead to the fact that $72 \%$ of the organizations often miss crucial growth opportunities (Alon et al., 2016).

(3) In rigidly bureaucratic structures of the public sector, the innovation implementation in most cases is due to a crisis, change of the government, adoption of new national strategic documents, policies, etc. That is why innovations, as a rule, are implemented from top to bottom that cause resistance of the staff of public institutions and complicates the development of pro-innovative culture. However, internal problems (such as the incapability to meet the demand for a program, financial resource constraints, or an incapability to coordinate policies) and new opportunities, created either by technology or other factors should be noted as important antecedents for innovation as well (Borins, 2001). Therefore, for many public services, change and/or innovation are due to both political decisions and the need to overcome a performance gap. In this connection, the organizational locus of innovation is important. Perhaps the more intriguing findings are that "top-down innovation is primarily concerned with organizational and service efficiency while bottom-up innovation is concerned primarily with organizational and service effectiveness" (Osborne \& Brown, 2011, p. 1342), and "bottom-up innovations may have broad-reaching consequences whereas the top-down innovations may be largely ineffective" (Moldogaziev \& Resh, 2016, p. 689). This means that creative abilities and innovative behavior must be developed not only in senior executives but also in the middle and frontline staff of public institutions.

(4) A profit motive is absent in public institutions, and the need for innovation is often linked to social or environmental challenges, redistrib- utive or consumption-related goals that are unique. It is undoubtedly the case that the innovation outcomes largely depend on the financial and intellectual resources, leadership, and entrepreneurial qualities of senior executives as well as on the level of transparency of public institutions (this is one of the key factors of improving public sector performance) and effectiveness of their cooperation with all stakeholders. However, the use of effective tools is often hampered by a rigid regulatory framework, the complexity of forming ad hoc structures, and strict control over the use of budgets that are generated by taxpayers. Although such control can prevent or detect corruption, it constrains innovations in the public sector.

(5) It is difficult to collect data for empirical research related to the analysis of innovation in the public sector without the support of the government or local self-government leaders, because they may not be interested in the promulgation of the results of such studies and their free interpretation by experts. After all, this can negatively affect the image of politicians and the results of the next election. Trying to be open, political and administrative elites often overestimate the positive outcomes of the innovations initiated by them and justify the lack of tangible effect for the population due to peculiarities of long-term implementation changes in the public sector. This limits the possibility of public institutions to self-report on the adoption of innovation (Damanpour et al., 2009). For instance, in 2019 the National Agency of Ukraine for Civil Service announced the results of the performance evaluation of experts on reforms who are change agents in the government. The results are impressive: $95 \%$ of KPIs are fully implemented, $2.6 \%$ are not evaluated according to legislation and only $2.4 \%$ are not fully implemented (National Agency of Ukraine for Civil Service, 2019). Thus, there are three options for explaining these indicators:

a) the necessary changes were introduced, but the society did not feel their results, because more time is needed; 
b) KPIs were related to the execution of current work, not the implementation of real changes;

c) KPIs were focused on the implementation of reforms, but the assessment of their implementation was not objective (the human factor).

(6) Due to the lack of a market for administrative services, the innovation outcomes can be measured not on the basis of financial or quantitative, but mainly the qualitative indicators (for example, improved user satisfaction, more targeted services, societal and environmental benefits, etc.). The assessment of such indicators is subjective. In addition, the public service innovations can result in the prevention of marginalization, increased social security, besides combining effectiveness and public service quality (Allio, 2014). Therefore, information about different types of innovations is incomparable. Besides, it is impossible to determine accurately the cost savings resulting from the introduction of innovations in the public sector, especially if they are accompanied by other changes, reorganization of public authorities, creation of professional networks and new ecosystems, etc.

Experts use various criteria for identifying and measuring innovation, grouped into frameworks, such as the following: EPSIS - European Public Sector Innovation Scoreboard (European Commission, 2013); NESTA - The Public Sector Innovation Indices (Hughes et al., 2011); APSII The Australian Public Sector Innovation Indicators (Arundel \& Huber, 2013); EPSA - European Public Sector Awards (Burnett \& Rongione, 2019); criteria of the Innovation in American Government Awards (ASH Center for Democratic Governance and Innovation, 2019), etc. Over time, the problem is complicated by the fact that the number of criteria is increasingly growing, and once institutionalized, they are proving to be very difficult to remove (OECD, 2019).

Consequently, the main problems of innovation capacity in the public sector are related to a rigid bureaucratic system of public institutions, the self-protective leadership style of their senior executives, low level of the productive activity of pub- lic servants, and their misunderstanding of the difference between processes of minor improvements and innovation, rigid control and lack of investments, as well as the difficulty of recognition, measurement, and dissemination of innovations.

\subsection{The development opportunities for innovative design labs for the public sector in the regions of Ukraine}

Empirical data that indicates a high level of functional incompetence of public servants in Ukraine was emphasized in the literature review. At the regional level, this problem is exacerbated in the context of the decentralization reform. Newly created amalgamated territorial communities form project units that carry out project-oriented management. The problem is that bureaucratic public institutions in the regions of Ukraine lack pro-innovative culture, specialists with skills for innovation, experience in innovative projects realization, and scientific potential for implementing effective tools for the development of public innovation capacity. This prompted the creation of e an innovative design lab on the basis of the Institute of Humanities and Public Administration (IHPA) in the framework of realization of the joint Ukrainian-Lithuanian R\&D project.

LIDER constituent documents and the strategy of its activity should be developed based on the results of the SWOT-analysis. The SWOT-matrix (Table 1) has been designed, taking into account the aspects considered in the previous paragraph. It includes the key internal and external factors that determine the development opportunities for the LIDER.

As a result of the SWOT-analysis, the possibilities of using the strategic links, which are schematically presented in Table 2, were identified. Unfortunately, there are no strategic links between the inhibitors $\left(\mathrm{W}_{6}, \mathrm{~T}_{7}\right)$ and the enhancers. Therefore, in the future, it will be extremely difficult to eliminate them.

The results of empirical and theoretical studies allow identifying the following development opportunities for the LIDER as an innovative design lab: 
Table 1. SWOT-matrix for analysis of the development opportunities for the LIDER

\begin{tabular}{|c|c|}
\hline Enhancers & Inhibitors \\
\hline Strengths & Weaknesses \\
\hline $\begin{array}{l}\mathrm{S}_{1}-\text { IHPA is a social enterprise, which sells educational services on the market and } \\
\text { fulfills state orders with guaranteed funding; } \\
\mathrm{S}_{2}-\text { IHPA has a good reputation as a regional provider of quality educational } \\
\text { services; } \\
\mathrm{S}_{3}-\text { IHPA has created an expert environment; } \\
\mathrm{S}_{4}-\text { Well-established relationships with stakeholders; } \\
\mathrm{S}_{5} \text { - Experience in implementing R\&D projects; } \\
\mathrm{S}_{6}-\text { Scientific school "Management of processes of intellectualization in socio- } \\
\text { economic systems" of the IHPA has successful experience in developing models of } \\
\text { human resources intellectualization; } \\
\mathrm{S}_{7}-\text { The ability to develop core skills for public sector innovation with an eye to the } \\
\text { future needs; } \\
\mathrm{S}_{8}-\text { Multidisciplinarity and the ability to form ad hoc project teams to mobilize } \\
\text { innovative forces; } \\
\mathrm{S}_{9}-\text { Impartiality, limited ambition to increase own bureaucratic influence on public } \\
\text { institutions; } \\
\mathrm{S}_{10}-\text { Ability to provide learning from both theory and practical experience of } \\
\text { the innovative solutions, as well as integration of training activity with scientific } \\
\text { research; } \\
\mathrm{S}_{11}-\text { Experience in the development of pro-innovative corporate culture; } \\
\mathrm{S}_{12} \text { - Experience in the implementation of transformative learning programs and } \\
\text { development of senior executives of public institutions; } \\
\mathrm{S}_{13}-\text { Availability of own trainers with European certificates; } \\
\mathrm{S}_{14} \text { - Experience in using HR data and developing a system of employee motivation } \\
\text { based on KPIs. }\end{array}$ & $\begin{array}{l}\text { W }- \text { Lack of normative component in the } \\
\text { interpretation of innovation in the public sector } \\
\text { that complicates the evaluating performance of } \\
\text { the LIDER; } \\
\text { W }_{2} \text { - Lack of instruments for developing and } \\
\text { testing public innovation capacity; } \\
\text { W }_{3} \text { - Lack of influence on introduction of } \\
\text { innovations and other changes in public } \\
\text { institutions; } \\
\text { W }_{4}-\text { Inability to holistically monitor the process of } \\
\text { innovation implementation in public institutions } \\
\text { due to limited access; } \\
\text { W }_{5}-\text { Insufficient financial resources to compete } \\
\text { with associations that provide educational services } \\
\text { free of charge through international technical } \\
\text { assistance; } \\
\text { W }_{6}-\text { The lack of a market for educational services } \\
\text { for public servants complicates strategic planning; } \\
\text { W }_{7}-\text { A large amount of creative analytical work } \\
\text { at the LIDER with a low level of financing from the } \\
\text { state budget. }\end{array}$ \\
\hline
\end{tabular}
based on KPIs.

\section{Opportunities}

\section{Threats}

$\mathrm{O}_{1}$ - The need for new educational services in the context of public administration reform and formation of a market for educational services for public servants;

$\mathrm{O}_{2}$ - Opportunity to involve foreign experts and investments in implementing international R\&D projects through EU technical assistance;

$\mathrm{O}_{3}$ - Open collaboration with all stakeholders without political influence and bureaucratic restrictions:

$\mathrm{O}_{4}$ - Opportunity to organize competitions for innovative projects of public institutions to develop the LIDER image;

$\mathrm{O}_{5}$ - Professional network of scholars and practitioners will help to disseminate the best practices in public institutions;

$\mathrm{O}_{6}-$ Ability to train public servants in the application of design thinking approaches;

$\mathrm{O}_{7}$ - Possibility to strengthen ties between public servants and academics;

$\mathrm{O}_{8}$ - Low institutional capacity of public institutions to introduce changes, that increases the demand for the LIDER's services;

O - Possibility to delegate experts to public councils at local self-government bodies after the 2020 local elections;

$\mathrm{O}_{10}$ - Possibility to use cloud technologies for collaboration in the development of projects, blended learning, etc.;

$\mathrm{O}_{11}-$ Ability to conduct benchmarking to scale innovations.

$T_{1}$ - Low solvency of public institutions for the LIDER services in a crisis;

$\mathrm{T}_{2}$ - Problems with primary data collection on innovation without supporting public institution leaders;

$\mathrm{T}_{3}$ - The development of the market for educational services for public servants will lead to competition with private providers;

$\mathrm{T}_{4}$ - COVID-19 pandemic complicates planning for participation of foreign experts in training for public servants in Ukraine;

$\mathrm{T}_{5}$ - New challenges will constantly arise under the influence of the global financial crisis;

$\mathrm{T}_{6}$ - Long-term implementation of changes and innovations in the public sector and overestimating its positive outcomes by the leaders of public institutions;

$\mathrm{T}_{7}$ - Performance will be significantly affected by the human factor.

Table 2. Possibilities for using the strategic linkages from the SWOT-matrix for developing the LIDER

\begin{tabular}{|c|c|}
\hline Questions for analysis & Strategic linkages \\
\hline What strengths can be used to realize opportunities? & $\begin{array}{l}\mathrm{S}_{5}, \mathrm{~S}_{6}, \mathrm{~S}_{7}, \mathrm{~S}_{11}, \mathrm{~S}_{12}, \mathrm{~S}_{14} \rightarrow \mathrm{O}_{1} ; \mathrm{S}_{6}, \mathrm{~S}_{8} \rightarrow \mathrm{O}_{2} ; \mathrm{S}_{3}, \mathrm{~S}_{4}, \mathrm{~S}_{9} \rightarrow \mathrm{O}_{3^{\prime}} \\
\mathrm{S}_{10^{\prime}} \mathrm{S}_{13} \rightarrow \mathrm{O}_{6} ; \mathrm{S}_{3}, \mathrm{~S}_{4} \rightarrow \mathrm{O}_{4}, \mathrm{O}_{5^{\prime}}, \mathrm{O}_{7}, \mathrm{O}_{9}, \mathrm{O}_{11} ; \mathrm{S}_{5}, \mathrm{~S}_{8} \rightarrow \mathrm{O}_{8}\end{array}$ \\
\hline What weaknesses can be substituted by using opportunities? & $\mathrm{O}_{5} \rightarrow \mathrm{W}_{3} ; \mathrm{O}_{9} \rightarrow \mathrm{W}_{4} ; \mathrm{O}_{2} \rightarrow \mathrm{W}_{2}, \mathrm{~W}_{5}, \mathrm{~W}_{7}$ \\
\hline What strengths can be used to reduce threats? & $\mathrm{S}_{1}, \mathrm{~S}_{2}, \mathrm{~S}_{13} \rightarrow \mathrm{T}_{1}, \mathrm{~T}_{3} ; \mathrm{S}_{3} \rightarrow \mathrm{T}_{2} ; \mathrm{S}_{13} \rightarrow \mathrm{T}_{4} ; \mathrm{S}_{11} \rightarrow \mathrm{T}_{5}$ \\
\hline What weaknesses need to be addressed to reduce threats? & $\mathrm{W}_{5} \rightarrow \mathrm{T}_{1} ; \mathrm{W}_{2} \rightarrow \mathrm{T}_{2}$ \\
\hline What weaknesses can be corrected by using strengths? & $\begin{array}{l}\mathrm{S}_{3}, \mathrm{~S}_{5}, \mathrm{~S}_{6} \rightarrow \mathrm{W}_{1} ; \mathrm{S}_{6}, \mathrm{~S}_{8} \rightarrow \mathrm{W}_{2} ; \mathrm{S}_{3}, \mathrm{~S}_{4}, \mathrm{~S}_{9} \rightarrow \mathrm{W}_{3}, \mathrm{~W}_{4} \\
\mathrm{~S}_{1} \rightarrow \mathrm{W}_{5}\end{array}$ \\
\hline What threats can be reduced by using opportunities? & $\begin{array}{l}\mathrm{O}_{2} \rightarrow \mathrm{T}_{1} ; \mathrm{O}_{3}, \mathrm{O}_{4^{\prime}} \mathrm{O}_{9^{\prime}} \mathrm{O}_{11} \rightarrow \mathrm{T}_{2} ; \mathrm{O}_{4^{\prime}} \mathrm{O}_{6}, \mathrm{O}_{7}, \mathrm{O}_{10}, \mathrm{O}_{11} \rightarrow \mathrm{T}_{3} ; \\
\mathrm{O}_{10} \rightarrow \mathrm{T}_{4} ; \mathrm{O}_{9} \rightarrow \mathrm{T}_{6}\end{array}$ \\
\hline
\end{tabular}


(1) Unlike other regional providers of educational services for public servants who do not have scientific potential, the LIDER activities should not focus on developing knowledge and improving professional skills such as public procurement, prevention of corruption, drafting analytical documents, etc., but on promoting the introduction of incremental innovations in public institutions. The implementation of this direction will be facilitated by the realization of the joint UkrainianLithuanian R\&D project "Competence Development of Lithuanian and Ukrainian Public Sector Employees Using DesignThinking Methodology" in 2020-2021. In particular, the project involves practical-oriented training for public servants using the design thinking methodology. This social technology can deliver the following benefits to public decision-making: a human-centric perspective of defining the user needs (need seeker mentality by focusing on the person, not on the product); problem-solving through creativity, multidisciplinarity and teamwork; application of experimental and holistic approaches to reduce risks; targeted solutions that are "good enough for now" as a starting point for continued innovation instead of dubious attempts to solve a global problem.

(2) An important area of activity aimed at ensuring the formation of the innovation capacity of public institutions is the development of their pro-innovative culture and participative leadership. Therefore, the LIDER cooperation with the scientific school "Management of processes of intellectualization in socio-economic systems" should ensure the development of effective tools for performance management in public institutions, the development of their organizational culture and leadership via individual-centric and system-oriented approaches. The use of the latter provides the following advantages: involvement of senior executives as well as other specialists of a public institution in the analysis of the problems of its functioning and development; identifying the problems of leadership in a public institution on the basis of assessing not only the qualities of its senior executives but also structure and relationships of the organizational system, its processes, interaction of elements, development dynamics, organizational culture, etc.; formation of the content and methods of training on the leadership development in a public institution on the basis of the results of empirical research.

(3) The lack of market for educational services for public servants and the low solvency of public institutions cause the need to find opportunities for implementing the training activities through EU technical assistance. The purpose of the participation of the LIDER in grants competitions is not only to attract financial resources but also to demonstrate its success in project management. Strengthening cooperation with public institutions regularly will be facilitated by their support in project activity development.

(4) The creation of a good image of the regional innovation accelerator will be facilitated by the annual organization of competition for innovative projects. It is advisable to take into consideration the experience of using the following tools: EPSIS, NESTA, APSII, EPSA, criteria of the Innovation in American Government Awards, etc. These ensure the achievement of two key goals, namely: countering political animosity to the public service and mass-media criticism (Borins, 2001) and encouraging the scaling innovations that have been implemented in Ukraine in terms of native legislation and culture (Dzvinchuk et al., 2020). Funding for the competition should be included in the regional development programs.

(5) The LIDER in cooperation with the scientific school and public institutions should not just adopt technologies, but promote the creation of radically human systems for the formation of the innovation capacity of public institutions based on the use of HR analytics. At that point, the experience of the Office of Human Resources Management and the NGO "Partnership for Public Service" (the USA) in conducting the annual survey "Federal Employee Viewpoint Survey" (OPM, 2019) is useful. The results of this study are used by senior executives of federal agencies in deci- 
sion-making on individual and institutional development. Since the goal is to develop the innovation capacity of public institutions, the analysis tool should be developed according to the following logic: project management, par- ticipative leadership, pro-innovative organizational culture, performance management $\rightarrow$ motivation, and the ability of public servants to implement changes and innovations $\rightarrow$ institutional capacity for innovation.

\section{CONCLUSION}

The purpose of the study was to define the development opportunities for innovative design labs for the public sector in the regions of Ukraine using the case of the Laboratory of Intellectual Development for Empowering Regions (LIDER) based on the analysis of the main features and problems of the innovation capacity of public institutions.

The following main features for public institutions were detected:

1. lack of profit motive, therefore the project approval is not dependent on future revenues, and the need for innovation is often associated with social or environmental challenges, redistributive or consumption related goals, which are unique;

2. not only the result, but the process of implementing innovations is important, therefore it is necessary to measure innovation holistically and with a bias for action;

3. a need for seeker mentality and necessity to ensure transparency of public institutions' activity cause engaging customers directly to generate new ideas and open collaborations with stakeholders.

The study provided the identification of the main barriers to innovation introduction in public institutions, namely: rigid bureaucratic systems; the ambiguity of the term "innovation" and its types in the public sector; measurement of innovations can be a problem because of long-term implementation and over-estimating its positive outcomes by political and administrative elites; the result of innovations is mainly assessed on the basis of qualitative indicators, and therefore is rather subjective; situational political decision-making; low level of the productive activity of public servants.

The identified problems of creating and ensuring the efficiency of innovative design labs in the regions of Ukraine are related to the fact that bureaucratic public institutions lack pro-innovative culture, specialists with skills for innovation, experience in innovative projects realization, the scientific potential for implementation of the effective tools for developing and testing public innovation capacity. Therefore, the development opportunities for the LIDER as an innovation accelerator are the following: orientation its activity not so much on developing knowledge and improving professional skills of public servants as on promoting the introduction of incremental innovations in public institutions by using design thinking methodology in training for public servants; development the effective tools for performance management in public institutions; assistance in developing their pro-innovative culture and participative leadership via individual-centric and system-oriented approaches; supporting public institutions in their project activity development; organization of competitions for regional innovative projects to ensure the scaling innovations that have been implemented in Ukraine in terms of native legislation and culture; assistance in the creation of radically human systems for the formation of the innovation capacity of public institutions.

\section{AUTHOR CONTRIBUTIONS}

Conceptualization: Dmytro Dzvinchuk, Mariana Orliv, Brigita Janiunaite.

Data curation: Mariana Orliv, Victor Petrenko. 
Formal analysis: Mariana Orliv, Victor Petrenko.

Investigation: Dmytro Dzvinchuk, Mariana Orliv, Brigita Janiunaite, Victor Petrenko.

Methodology: Mariana Orliv, Brigita Janiunaite.

Project administration: Dmytro Dzvinchuk, Brigita Janiunaite.

Validation: Dmytro Dzvinchuk, Victor Petrenko.

Visualization: Mariana Orliv.

Writing - original draft: Mariana Orliv, Brigita Janiunaite, Victor Petrenko.

Writing - review \& editing: Dmytro Dzvinchuk, Mariana Orliv.

\section{ACKNOWLEDGMENT}

The paper was prepared within the framework of the joint Ukrainian-Lithuanian R\&D project "Competence Development of Lithuanian and Ukrainian Public Sector Employees Using DesignThinking Methodology".

The project has received funding from the Research Council of Lithuania (LMTLT, agreement № S-LU-20-5) and the Ministry of Education and Science of Ukraine (agreement № M/31-2020).

\section{REFERENCES}

1. Afonin, E. A., \& Balakireva, O. M. (2015). Functional readiness and competence of civil servants in Ukraine to exercise public administration in the context of democracy Ukrainskyi Sotsium - Ukrainian Society, 1, 7-22. (In Ukrainian). https://doi. org/10.15407/socium2015.01.007

2. Allio, L. (2014). Design thinking for public service excellence. Singapore: GCPSE, UNDP. Retrieved from https://www.undp. org/content/dam/undp/library/ capacity-development/English/ Singapore\%20Centre/GPCSE_Design\%20Thinking.pdf

3. Alon, A., Elron, D., \& Jackson, L. (2016). Innovation: clear vision, cloudy execution. 2015 US Innovation Survey. Accenture. Retrieved June 05, 2020 from https://www.accenture.com/ t20180705t112257z_w__us-en/_ acnmedia/pdf-10/accenture-innovation-research-execsummary.pdf

4. Apolitical. (2019). Mapped: The innovation labs transforming government - and how to get in touch. Innovation Lab Directory. Retrieved May 20, 2020 from https://apolitical.co/governmentinnovation-lab-directory/

5. Arundel, A., \& Huber, D. (2013). From too little to too much innovation? Issues in measuring innovation in the public sector. Structural Change and Economic Dynamics, 27, 146-159. https://doi. org/10.1016/j.strueco.2013.06.009

6. Arundel, A., Bloch, C., \& Ferguson, B. (2019). Advancing innovation in the public sector: Aligning innovation measurement with policy goals. Research Policy, 48(3), 789-798. https://doi.org/10.1016/j. respol.2018.12.001

7. ASH Center for Democratic Governance and Innovation. (2019). Selection criteria. Harvard Kennedy School. Retrieved June 03, 2020 from https://ash.harvard.edu/iagselection-criteria

8. Berry, F. S., \& Berry, W. D. (1990). State lottery adoptions as policy innovations: an event history analysis. American Political Science Review, 84(2), 395-415. https://doi. org/10.2307/1963526

9. Bloch, C. (2011). Measuring Public Innovation in the Nordic Countries (MEPIN) (Report). Retrieved from http://www.diva-portal.org/smash/ get/diva2:707193/FULLTEXT01.pdf

10. Borins, S. (2001). Encouraging innovation in the public sector. Journal of Intellectual Capital, 2(3), 310-319. https://doi. org/10.1108/14691930110400128
11. Bugge, M. M., \& Bloch, C. W. (2016). Between bricolage and breakthroughs - framing the many faces of public sector innovation. Public Money \& Management, 36(4), 281-288. https://doi.org/10.1 080/09540962.2016.1162599

12. Burnett, M., \& Rongione, C. (2019). New solutions to complex challenges: A public sector citizencentric, sustainable and fit for the future. European Institute of Public Administration. Retrieved May 15, 2020 from https://epsa2019.eu/ files/repository/20191105092657_ EPSA2019_publication_web.pdf

13. Damanpour, F., Walker, R. M., \& Avellaneda, C. N. (2009). Combinative effects of innovation types and organizational performers: A longitudinal study of service organizations. Journal of Management Studies, 46(4), 650675. https://doi.org/10.1111/j.14676486.2008.00814.x

14. De Vries, H., Bekkers, V., \& Tummers, L. (2015). Innovation in the public sector: A systematic review and future research agenda. Public Administration, 94(1), 146-166. https://doi.org/10.1111/ padm.12209

15. Demircioglu, M. A., \& Audretsch, D. B. (2017). Conditions for innovation in public sector organiza- 
tions. Research Policy, 46(9), 16811691. https://doi.org/10.1016/j. respol.2017.08.004

16. Demircioglu, M. A., \& Audretsch, D. B. (2018). Conditions for complex innovations: evidence from public organizations. The Journal of Technology Transfer, 45(3), 820-843. https://doi.org/10.1007/ s10961-018-9701-5

17. Dzvinchuk, D. I., Petrenko, V. P., Orliv, M. S., \& Molodtsov, O. V. (2020). Three-dimensional model of the institutional matrix as a methodological tool for designing institutional changes. Revista Galega De Economía, 29(1), 1-15. https://doi.org/10.15304/ rge.29.1.6236

18. European Commission. (2013). European public sector innovation scoreboard 2013 - A pilot exercise. Retrieved May 17, 2020 from https:/op.europa.eu/en/ publication-detail/-/publication/ fe2a3b4b-3d7e-444d-82bc790a0ab33737

19. European Commission. (2019). European innovation scoreboard 2019. Retrieved from https:// op.europa.eu/en/publicationdetail/-/publication/d156a01b9307-11e9-9369-01aa75ed71a1/ language-en/format-PDF/ source-136061387

20. Gellen, M. (2017). Bureaucrats as innovators? Statistical analysis on innovative capacity within the Hungarian central civil service. Transylvanian Review of Administrative Sciences, 12(SI), 38-54. Retrieved from https://rtsa. ro/tras/index.php/tras/article/ view/503

21. GLOBE. (2020). Global Leadership and Organizational Behavior Effectiveness: Overview. Retrieved June 10, 2020 from https://globe. bus.sfu.ca/studies

22. Harb, B., \& Sidani, D. (2019). Transformational leadership for organizational change in the Lebanese public sector. Problems and Perspectives in Management, 17(2), 205-216. https://doi. org/10.21511/ppm.17(2).2019.15

23. Hughes, A., Moore, K., \& Kataria, N. (2011). Innovation in public sector organisations: A pilot survey for measuring innovation across the public sector (Report). NESTA. Retrieved from shorturl.at/bcdB6

24. Lapuente, V., \& Suzuki, K. (2020) Politicization, bureaucratic legalism, and innovative attitudes in the public sector. Public Administration Review, 80(3), 454-467. https:// doi.org/10.1111/puar.13175

25. Lau, A., Yusoff, D., \& Faisall, Sh. (2016). Design-led innovation in the Singapore public service. The Human Experience Lab, Public Service Division. Singapore. Retrieved March 27, 2020 from https://docplayer.net/50118553Design-led-innovation-in-thesingapore-public-service.html

26. Meijer, A. (2019). Public innovation capacity: Developing and testing a self-assessment survey instrument. International Journal of Public Administration, 42(8), 617-627. https://doi.org/10.1 080/01900692.2018.1498102

27. Moldogaziev, T. T., \& Resh, W. G. (2016). A Systems theory approach to innovation implementation: Why organizational location matters. Journal of Public Administration Research and Theory, 26(4), 677-692. https://doi.org/10.1093/ jopart/muv047

28. National Agency of Ukraine for Civil Service. (2019). Uzahalnena statystychna informatsiia shchodo rezultativ otsiniuvannia sluzhbovoi diialnosti fakhivtsiv z pytan reform za 2018 rik [Generalization of statistical information on the results of performance appraisal of specialists on reforms for 2018] (Statistics). (In Ukrainian). Retrieved April 27, 2020 from https://nads.gov.ua/storage/app/ sites/5/human\%20resourses/32. pdf

29. OECD \& Eurostat. (2018). Oslo manual: guidelines for collecting, reporting and using data on innovation ( $4^{\text {th }}$ ed.). Paris/Eurostat and Luxemburg: OECD Publishing. https://doi. org/10.1787/9789264304604-en

30. OECD. (2018). HR and leadership strategies for building innovative public sector organisations. Retrieved June 21, 2020 from https://oecd-opsi.org/wp-content/ uploads/2019/03/HR-and-Leadership-Catalyst-for-InnovationCapabilities.pdf

31. OECD. (2019). Observatory of public sector innovation. Retrieved May 15, 2020 from https:// oecd-opsi.org/wp-content/uploads/2019/05/Measuring-PublicSector-Innovation-Part-5b-ofLifecycle.pdf

32. OPM. (2019). Federal employee viewpoint survey: Empowering employees. Inspiring change. Office of Personnel Management. Retrieved May 25, 2020 from https://www.opm.gov/fevs/

33. Osborne, S. P., \& Brown, L. (2011). Innovation, public policy and public services delivery in the UK. The word that would be king? Public Administration, 89(4), 1335-1350. https://doi.org/10.1111/j.14679299.2011.01932.x

34. Rao, A., Hurley, B., Khan, A., \& Bhat, R. (2019). Government trends 2020: A report from the Deloitte Center for Government Insights (Report). Retrieved June 21, 2020 from https://www2. deloitte.com/content/dam/ insights/us/articles/governmenttrends-2020/DI_GovernmentTrends-2020.pdf

35. Sahni, N. R., Wessel, M., \& Christensen, C. (2013). Unleashing breakthrough innovation in government. Stanford Social Innovation Review. Retrieved June 24, 2020 from https://ssir. org/pdf/Summer_2013_Unleashing_Breakthrough_Innovation_in_ Government.pdf

36. Sandor, S. D. (2018). Measuring Public Sector Innovation. Transylvanian Review of Administrative Sciences, 14(54), 125-137. http://dx.doi. org/10.24193/tras.54E.8

37. Suzuki, K., Ha, H., \& Avellaneda, C. N. (2020). Direct and non-linear innovation effects of demographic shifts. Australian Journal of Public Administration, 79(3), 351-369. https://doi. org/10.1111/1467-8500.12424 
38. Teodoro, M. P. (2009). Bureaucratic job mobility and the diffusion of innovations. American Journal of Political Science, 53(1), 175-189. https://doi.org/10.1111/j.15405907.2008.00364.x

39. Torugsa, N., \& Arundel, A. (2016). Complexity of innovation in the public sector: A workgroup-level analysis of related factors and outcomes. Public Management Review, 18(3), 392-416. https://doi.org/10.1 080/14719037.2014.984626

40. Windrum, P. (2008). Innovation and enterpreneurship in public service. In P. Windrum \& $\mathrm{P}$. Koch (Eds.), Innovation in Public Sector Services, 1, 3-20. Edward Elgar Publishing. Retrieved from https://ideas.repec.org/h/elg/eechap/4030_1.html

41. Witell, L., Snyder, H., Gustafsson, A. Fombelle, P., \& Kristensson, P. (2016). Defining service innovation: A review and synthesis. Journal of Business Research, 69(8), 2863-2872. https://doi. org/10.1016/j.jbusres.2015.12.055

42. World Bank Group. (2018). Improving public sector performance: Through innovation and inter-agency coordination (Report). Retrieved June 21, 2020 from http://documents.worldbank.org/curated/ en/833041539871513644/ pdf/131020-WP-P163620-WorldBankGlobalReport-PUBLIC.pdf

43. Zidonis, Z., Bilinskyi, D., \& Nazyrov, K. (2020). Management innovation practices to public sector organizations. Problems and Perspectives in Management, 18(3), 392-401. https://doi.org/10.21511/ ppm.18(3).2020.32 